\title{
Pembunuhan Suami oleh Istri dalam Konteks Kekerasan dalam Rumah Tangga dan Penghukuman yang Dialaminya
}

\author{
Vinita Susanti \\ Departemen Kriminologi-FISIP \\ Universitas Indonesia, Depok \\ email:vinitasusanti@yahoo.com
}

\begin{abstract}
This article discusses the experience of women accused of 'killing' their husbands, with the punishment they experienced. The type of research is feminist, with a qualitative approach. Women who commit killings against their own husbands, in criminology are said to be 'typical' crimes. In a positivist (normative) legal review, these women are said to be perpetrators of murder crimes. From a criminological point of view, the perpetrator actually shows his position as a victim of domestic violence. The crimes committed by them are gender-based crimes. The focus of this paper is about punishments given to those who do not always use the PKDRT Law, even though they are within the household sphere. This study showed the experience of wives accused of being the perpetrators of murder crimes, who were victims, which had implications for the form of punishment against them. In criminology known as victims who become perpetrators.
\end{abstract}

Keywords: victims and perpetrators; sexual harrasment; punishment

Abstrak: Tulisan ini membahas tentang pengalaman perempuan yang dituduh 'membunuh' suami, dengan penghukuman yang dialaminya. Jenis penelitiannya feminis, dengan pendekatan kualitatif. Perempuan yang melakukan pembunuhan dimana terhadap suaminya sendiri, dalam kriminologi dikatakan sebagai kejahatan yang 'khas'. Dalam tinjauan hukum positivis (normatif), perempuan tersebut dikatakan sebagai pelaku kejahatan pembunuhan. Dari sudut pandang kriminologis, pelaku sebenarnya menunjukkan posisinya sebagai korban kekerasan dalam rumah tangga. Kejahatan yang dilakukan mereka adalah kejahatan yang berbasis gender. Fokus tulisan ini adalah tentang penghukuman yang diberikan kepada mereka yang tidak selalu menggunakan UU PKDRT, padahal mereka berada dalam lingkup rumah tangga. Penelitian ini menunjukkan pengalaman istri yang dituduh sebagai pelaku kejahatan pembunuhan, adalah korban, yang berimplikasi bentuk penghukuman terhadap mereka. Dalam kriminologi dikenal dengan korban yang menjadi pelaku.

Kata Kunci: korban dan pelaku; kekerasan seksual; penghukuman 


\section{A. Pendahuluan}

"To be born female is not a crime', dikatakan oleh Kofi Annan. ${ }^{1}$ ketika ia menjadi Sekjen PBB. Menjadi perempuan merupakan anugerah yang sangat indah yang diberikan Tuhan kepada seseorang. Perempuan diberi kelebihan untuk dapat mengandung, mempunyai anak dan menyusui. Akan tetapi, sebagai perempuan ternyata dalam perjalanan kehidupannya, menghadapi dan mengalami berbagai persoalan, baik persoalan secara individu maupun dalam kehidupannya bekeluarga. Dalam artikel ini, akan dibahas, pengalaman perempuan yang menjadi istri, dalam kehidupan rumah tangganya menjadi korban, yang pada akhirnya menjalani hukuman di penjara, sebagai pembunuh.

Acuan dari artikel ini adalah penelitian penulis, yang berjudul "Pembunuhan oleh Istri dalam Konteks Kekerasan dalam Rumah Tangga (KDRT): Studi terhadap Empat Terpidana Perempuan di Lembaga Pemasyarakatan Wanita Bandung" yang menggambarkan penghukuman pada masing-masing istri yang dianggap melakukan pembunuhan. Tujuan penulisan dari artikel ini, adalah untuk menunjukkan pengalaman istri yang dituduh sebagai pelaku kejahatan pembunuhan, adalah korban, yang berimplikasi pada bentuk penghukuman terhadap mereka.

Penelitian ini adalah penelitian feminis dengan pendekatan kualitatif, yang ingin menunjukkan istri yang membunuh suaminya termasuk kejahatan yang 'khas'. Dalam kriminologi dikenal dengan korban yang menjadi pelaku. Berikut ini adalah pembahasan mengenai kejahatan pembunuhan yang dilakukan oleh istri terhadap suaminya dilihat dari kacamata kriminologi feminis, adalah kejahatan yang berbasis gender. Penghukuman yang dijalani oleh mereka, dimana semua dalam lingkup yang sama, rumah tangga, akan tetapi dasar penghukuman tidak sama, tidak semua menggunakan UU Penghapusan Kekerasan dalam Rumah Tangga.

'Vinita Susanti, "The Typology of Women Victims Domination of Domestic Violence: Study of Gender Equality in Women's Prison in Bandung," dalam Proceeding Re-examining Governance: Strengthening Citizenship in the Changing World - ICoCSPA 2016 (Surabaya: FISIP Universitas Airlangga, 2016), 77-81. 


\section{B. Perempuan dan Kekerasan dalam Rumah Tangga}

Perempuan memang potensial menjadi korban kejahatan yang antara lain korban dari Kekerasan dalam Rumah Tangga (KDRT). Catatan Tahunan (CATAHU) Komnas Perempuan, ${ }^{2}$ jumlah kasus kekerasan terhadap perempuan pada tahun 2015, sebesar 321.752 kasus. Yang paling menonjol, sama seperti tahun sebelumnya, adalah KDRT yang mencapai angka 11.207 kasus (69\%), Pada ranah KDRT, kekerasan yang paling menonjol adalah kekerasan fisik 4.304 kasus (38\%), menempati peringkat pertama, disusul kekerasan seksual 3.325 kasus (30\%), psikis 2.607 kasus (23\%) dan ekonomi 971 kasus (9\%). Sejalan dengan data dari The World Health Organization (WHO), ${ }^{3}$ memperkirakan bahwa 5,3 juta wanita mengalami kekerasan di tangan pasangan mereka setiap tahunnya. Namun yang menjadi fokus kajian dalam artikel ini adalah penghukuman terhadap perempuan pelaku 'pembunuhan' dalam kasus kejahatan seksual, studi terhadap korban kekerasan dalam rumah tangga.

Beberapa kajian tentang perempuan, baik perempuan sebagai korban, maupun sebagai pelaku kejahatan, menyebutkan gender merupakan variabel penting dalam memahaminya. Hasil penelitian dari Mary E. Gifus, dan kawankawan, ${ }^{4}$ menyebutkan bahwa gender terkategori penting sebagai variabel sentral dalam memahami konteks dan makna dari kekerasan pasangan intim (Intimate Partner Violence). Organisasi Kesehatan melaporkan kekerasan domestik,, bahwa "apabila terjadi kekerasan oleh perempuan itu lebih cenderung dalam bentuk pertahanan diri".

Sementara penelitian Bitna Kim, dan kawan-kawan, tentang KDRT di Korea Selatan, dalam konteks budaya dan pengalaman alternatif pada pe-

${ }^{2}$ Komisi Nasional Anti Kekerasan terhadap Perempuan, "Kekerasan terhadap Perempuan Meluas: Negara Urgen Hadir Hentikan Kekerasan terhadap Perempuan di Ranah Domestik, Komunitas dan Negara: Catatan Kekerasan terhadap Perempuan tahun 2015," 2016, https://www. komnasperempuan.go.id/reads-catatan-tahunan-tentang-kekerasan-terhadap-perempuan-2016.

${ }^{3}$ Bitna Kim et al., "Domestic Violence and South Korean Women: the Cultural Context and Alternative Experiences," Violence and victims 25, no. 6 (2010): 814-30, http://www.ncbi.nlm.nih.gov/ pubmed/21287969.

${ }^{4}$ Mary E. Gilfus et al, "Gender and Intimate Partner Violence: Evaluating the Evidence," Journal of Social Work Education 46, no. 2 (2010): 245-63, https://doi.org/10.5175/JSWE.2010.200900019.

5Etienne G. Krug et al, "The World Report on Violence and Health," The Lancet 360, no. 9339 (2002): 1083-88, https://doi.org/10.1016/S0140-6736(02)11133-0. 
rempuan menunjukkan bahwa: 1) perempuan dipenjara karena membunuh pasangannya. 2) perempuan yang mengalami kekerasan, mencari tempat perlindungan. ${ }^{6}$ Penelitian lain menunjukkan bahwa perempuan biasanya menyalahkan diri untuk kejadian kekerasan dalam rumah tangga. Kim dan Titterington menguji hipotesis mereka, dengan menghubungkan pasangan wanita Korea Selatan yang membunuh, terhadap ideologi tradisionalnya, dan menemukan bahwa perempuan yang membunuh pasangan intim mereka memiliki sikap patriarkal kuat daripada perempuan dianiaya lain yang telah mencari aman di tempat penampungan. 8

Masyarakat yang tidak setara gender, dalam memutus hubungan perkawinan, perempuan yang sering menerima risiko sosial dan ekonomi. Dalam penelitian terbaru, Kim menemukan bahwa, dibandingkan dengan kelompok lain perempuan Korea Selatan (petugas polisi perempuan, dokter perempuan, dan pelaku perempuan) dengan perempuan yang membunuh pasangan intim mereka, secara signifikan lebih rendah mengambil risiko preferensi, sementara mereka melaporkan tingkat lebih tinggi, secara bermakna dukungan untuk norma-norma tradisional tentang gender peran dan kegiatan gender. ${ }^{10}$

Idealnya dalam keluarga, suami dan istri sebagai mitra dari pasangannya. Relasi hubungan kekuasaan antara perempuan dan laki-laki (relasi gender) ${ }^{11}$

${ }^{6}$ Kim etal., "Domestic Violence and South Korean Women..."

7Y. I. Song-Kim, "Battered Korean Women in The Urban United States," dalam Social Work Practice With Asian Americans, ed. S. M. Furuto et al. (Newbury Park, CA: Sage Publication Inc., 1992), 213-26.

${ }^{8}$ Bitna Kim dan Victoria B. Titterington, "Abused South Korean Women: A Comparison of Those Who Do and Those Who Do Not Resort to Lethal Violence," International Journal of Offender Therapy and Comparative Criminology 53, no. 1(2009): 93-112, https://doi.org/10.1177/0306624X07312772.

${ }^{9}$ Bitna Kim, "General Power-Control Theory of Women: Using a Multigroup SEM Approach to Testing Mean Differences" (Sam Houston State University, Huntsville, 2008); Bitna Kim et al., "Applicability of General Power-Control Theory to Prosocial and Antisocial Risk-Taking Behaviors Among Women in South Korea," The Prison Journal 92, no. 1 (2012): 125-50, https://doi.org/ $10.1177 / 0032885511429275$.

${ }^{10}$ Pengertian gender adalah peran-peran yang diharapkan terhadap perempuan ataupun lakilaki. Sementara, konstruksi gender adalah kepercayaan kultural mengenai gender. Termasuk di dalamnya mengenai "pantas" (sesuatu yang dianggap ideal atau diharapkan dilakukan) dari laki-laki dan perempuan.

${ }^{11}$ Gender merupakan hasil produksi manusia yang bergantung pada perilaku setiap orang yang 'melakukan gender'. Sebagai sebuah institusi sosial, gender merupakan sebuah proses penciptaan status-sosial yang jelas terlihat dari hak-hak dan kewajiban-kewajibannya. Baca: Judith Lorber, "The 
yang timpang berlangsung di dalam rumah, lingkungan kerja maupun dalam masyarakat pada umumnya. Kebanyakan perempuan menerimanya sebagai hal yang biasa dan kebanyakan laki-laki menganggapnya sebagai sesuatu yang benar. Belum banyak laki-laki dan perempuan yang memandang keadaan tersebut sebagai suatu wujud diskriminasi terhadap perempuan, dan menyadari bahwa konsekuensi dari diskriminasi tersebut adalah banyaknya terjadi berbagai tindak kekerasan terhadap perempuan.12 Dalam kaitan itu sesuai dengan pendapat Susan L. Miler, yang mengatakan bahwa kekerasan rumah tangga sudah merupakan suatu yang rahasia, dianggap sesuatu yang sifatnya pribadi dan bukan merupakan masalah sosial. ${ }^{13}$

Di Indonesia, hukum yang berlaku untuk membela korban KDRT adalah UU Penghapusan KDRT, ketentuan pidana terhadap pelanggaran KDRT diatur oleh Undang-Undang Republik Indonesia No. 23 Tahun 2004 tentang Penghapusan KDRT sebagai berikut: berdasarkan bentuk kekerasannya, KDRT dibagi menjadi 4 kategori, yakni: 1) Kekerasan fisik; adalah perbuatan apapun yang disengaja, walaupun dengan alasan menyatakan kekerasan, kemarahan, bahkan menghukum, dengan sasaran fisik, tubuh, dan bagian tubuh yang mengakibatkan rasa sakit, jatuh sakit atau bahkan luka; 2) Kekerasan psikologis; adalah perbuatan yang tidak menyasar fisik korban tetapi mengakibatkan ketakutan, hilangnya rasa percaya diri, hilangnya kemampuan untuk bertindak, timbuhnya rasa tidak berdaya, dan atau penderitaan psikis pada korban; 3) Kekerasan seksual; adalah setiap perbuatan pemaksaan hubungan seksual dengan cara tidak wajar dan/atau tidak disukai. Dan juga, pemaksaan hubungan seksual dengan orang lain, untuk tujuan komersial dan/atau tujuan tertentu, baik itu dengan sesama penghuni rumah tangga tersebut atau orang di luar rumah tangga tersebut; dan 4) Penelantaran rumah tangga; yang dimaksud adalah perbuatan menelantarkan orang dalam lingkup rumah

Social Contruction of Gender," in The Social Construction of Difference and Inequality: Race, Class, Gender and Sexuality, ed. Tracy E. Ore (California: Mayfield Publhising Company, 2000), 106-110.

${ }^{12}$ Lorber.

${ }^{13}$ Susan L. Miler, "Arres Policies for Domestic Violence and Their Implication for Baterred," dalam It is a Crime, Women and Justice, ed. Roslyn Muraskin (Upper Sadle River, New Jersey: Long Island University, 2000), 289. 
tangga, padahal orang tersebut harus dinafkahi, dirawat dan dipelihara. Penelantaran juga dialami seseorang jika berakibat ketergantungan ekonomi karena dibatasi atau dilarang untuk bekerja yang layak, di dalam atau di luar rumah sehingga korban berada dibawah kendali pelaku.

Proses dimana seseorang mengalami menjadi korban kekerasan atau viktimisasi, bisa berbentuk yang nyata, seperti kekerasan fisik, psikis, ekonomi, seksual maupun kekerasan yang tidak nyata, seperti kekerasan simbolik. Siapa pun dapat mengalami viktimisasi, baik itu jenis kelamin perempuan, maupun laki-laki.

\section{Korban Berperan Penting dalam Pembunuhan}

Dalam kaitan peristiwa kejahatan, korban dapat saja berperan penting, seperti yang dikatakan oleh Wolgang, ${ }^{14}$ bahwa korban (victim) secara langsung berperan dalam kejahatan. Berkaitan dengan peran perempuan pelaku pembunuhan di dalam keluarga, tidak terlepas juga dari peran korban (suaminya). Korban (victim) adalah orang-orang yang secara individual atau kolektif telah mengalami penderitaan, meliputi penderitaan fisik atau mental, penderitaan emosi, kerugian ekonomis atau pengurangan substansial hak-hak asasi melalui perbuatan-perbuatan atau pembiaran-pembiaran (omisionaris) yang melanggar hukum pidana yang berlaku di negara-negara anggota yang meliputi juga peraturan hukum yang melarang penyalahgunaan kekuasaan. ${ }^{15}$

Terkait Convention on The Elimination of All Forms of Discrimination Againts Women (CEDAW), di Indonesia, konvensi diratifikasi lewat dikeluarkannya UU No. 7 Tahun 1984, tentang Pengesahan Konvensi Mengenai Penghapusan Segala Bentuk Diskriminasi terhadap Perempuan. Dalam Pasal 1 Konvensi tersebut disebutkan diskriminasi terhadap perempuan ${ }^{16}$ akan berarti pembedaan, pengesampingan, atau pembatasan apapun, yang dibuat atas dasar jenis kelamin yang mempunyai pengaruh atau mengurangi atau menghapus-

\footnotetext{
${ }^{14}$ Martin F. Wolfgang, "Victim Precipitated Criminal Homicide," Journal of Criminal Law and Criminology 48, no. 1 (1957): 1-11, https://scholarlycommons.law.northwestern.edu/jclc.

${ }^{15}$ Arif Gosita, "Pemahaman Perempuan dan Kekerasan," dalam Masalah Korban Kejahatan: Kumpulan Karangan (Jakarta: Penerbit Universitas Trisakti, 2004), 44.

${ }^{16}$ Komnas Perempuan, "Konvensi tentang Penghapusan Segala Bentuk Diskriminasi terhadap Perempuan" (Jakarta: Komnas Perempuan, 2002), 300.
} 
kan pengakuan, penikmatan atau penggunaan hak-hak asasi manusia dan kebebasan pokok di bidang politik, ekonomi, sosial budaya, sipil atau bidang apapun lainnya oleh kaum perempuan, terlepas dari status perkawinan mereka, atas dasar persamaan antara laki-laki dan perempuan.

Untuk jaminan hak asasi manusia dan kebebasan-kebebasan pokok atas dasar persamaan dengan pria, ada dalam Pasal 3, yakni: Para negara peserta akan mengambil dalam semua bidang terutama di bidang politik, sosial, ekonomi dan budaya, semua tindakan yang tepat, termasuk perundang-undangan, untuk tujuan menjamin pengembangan sepenuhnya dan kemajuan perempuan, untuk menjamin mereka pada pelaksanaan dan penikmatan hak-hak asasi manusia dan kebebasan-kebebasan dasar atas dasar persamaan dengan laki-laki. ${ }^{17}$

Sebagai catatan, Kekerasan Dalam Rumah Tangga bukanlah persoalan domestik (privat) yang tidak boleh diketahui orang lain. Kekerasan jenis ini, merupakan salah satu sumbangan dari kajian gender atau kajian perempuan. KDRT merupakan pelanggaran hak asasi manusia dan kejahatan terhadap martabat kemanusiaan serta bentuk diskriminasi yang harus dihapuskan. UU ini merupakan jaminan yang diberikan negara untuk mencegah terjadinya kekerasan dalam rumah tangga, menindak pelaku KDRT, dan melindungi korban KDRT Undang-undang ini juga tidak bertujuan untuk mendorong perceraian, sebagaimana sering dituduhkan orang. UU PKDRT ini justru bertujuan untuk memelihara keutuhan rumah tangga agar harmonis dan sejahtera dengan mencegah segala bentuk kekerasan sekaligus melindungi korban dan menindak pelaku kekerasan dalam rumah tangga.

\section{Variasi Posisi Perempuan Korban KDRT yang Menjadi Pelaku Pembunuhan}

Merujuk hasil temuan Vinita, ${ }^{18}$ menunjukkan ada 4 model tipologi dominasi dan kapital, yakni:

\footnotetext{
${ }^{17}$ Komnas Perempuan.

${ }^{18}$ Vinita Susanti, "Pembunuhan oleh Istri dalam Konteks Kekerasan dalam Rumah Tangga (KDRT): Studi terhadap Empat Terpidana Perempuan di Lembaga Pemasyarakatan Wanita Bandung" (Disertasi, Departemen Sosiologi, FISIP UI, Depok, 2015).
} 
Vinita Susanti

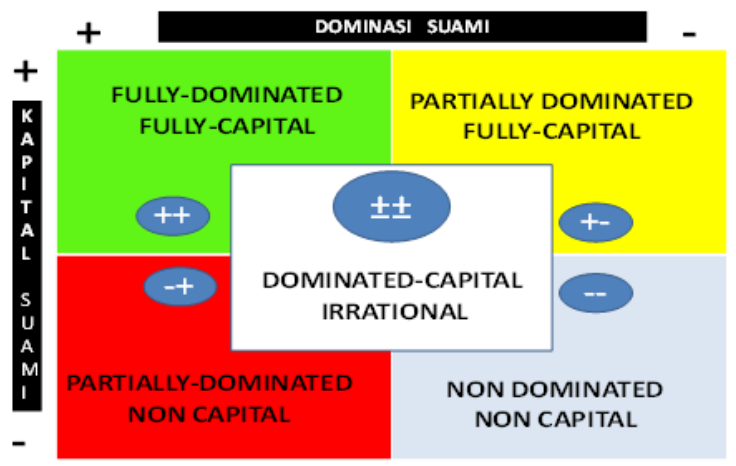

Gambar 1.

Matriks Tipologi Dominasi dan Kapital

\section{Pertama, Fully Dominated - Fully Capital \\ (Dominasi dan Kapital Suami Penuh)}

Pada tipologi ini, istri menjadi korban, karena berposisi dalam dominasi suami secara penuh dan secara kapital memenuhi ketergantungan pada suami, sehingga posisi demikian menjadikan istri sangat rentan mengalami viktimisasi (tetap tetap dalam konteks KDRT). Istri pada tipe ini, mengalami semua bentuk kekerasan, baik yang nyata maupun tidak nyata. Tabel 1. menunjukkan, kekerasan yang dialami oleh istri.

Tabel 1.

Viktimisasi dalam Kontek Kekerasan dalam Rumah Tangga

No. Aspek Viktimisasi dalam
Konteks KDRT

1 Kekerasan fisik $\quad \begin{aligned} & \text { Sering di pukul, yang paling fatal di pukul } \\ & \text { kepalanya. Informan III berbohong pada } \\ & \text { dokter, dengan mengatakan tertimpa } \\ & \text { besi. Dokter tertawa dan menatakan, } \\ & \text { kalau itu benar, akibatnya kematian. } \\ & \text { - } \\ & \text { Pernah di telanjangi, ketika suaminya } \\ & \text { marah-marah, baju di robek-robek, dan } \\ & \text { di usir dari rumah, 'dijorokin' (=didorong) } \\ & \text { ke empang seperti sampah }\end{aligned}$




\begin{tabular}{|c|c|c|}
\hline 2 & Kekerasan seksual & $\begin{array}{l}\text { - "Dipaksa” berhubungan suami istri, } \\
\text { kapanpun suami menginginkannya. Tidak } \\
\text { peduli sedang sakit, menstruasi, mau } \\
\text { shalat ataupun sedang berpuasa } \\
\text { Ramadhan. } \\
\text { - } \quad \text { Pernah dipaksa 'sodomi' ( } 2 x) \text {, karena } \\
\text { suami minum obat kuat. } \\
\text { - Bila suami 'main perempuan' (baik gadis } \\
\text { maupun janda), Informan III selalu } \\
\text { dipukuli. }\end{array}$ \\
\hline 3 & Kekerasan psikis & $\begin{array}{l}\text { - Diancam untuk mau menikah. } \\
\text { - Dua bulan nikah, baru tahu suaminya } \\
\text { - Sujingan'. } \\
\text { Suami 'main perempuan'. la pernah } \\
\text { lain di mobil suaminya. } \\
\text { - Pernah memergoki suaminya sedang } \\
\text { berduaan dengan menantu } \\
\text { perempuannya di dalam kamarnya. } \\
\text { - Suami egois dan mau menang sendiri. }\end{array}$ \\
\hline 4 & Kekerasan ekonomi & $\begin{array}{l}\text { - Uang bulanan diberikan kalau suami tidak } \\
\text { sedang 'main perempuan'. }\end{array}$ \\
\hline
\end{tabular}

Sumber: Hasil Penelitian, 2015

\section{Kedua, Partially Dominated - Non Capital \\ (Dominasi Suami Sebagian - Kapital Suami tidak Penuh)}

Pada tipologi ini, istri menjadi korban. Istri berposisi dalam dominasi suami secara penuh, namun suami tidak berkuasa dalam bidang kapital. Hal ini karena istri bekerja dari sebelum menikah, sementara suami bekerja tidak dengan penghasilan yang lebih tinggi daripada suaminya. Secara penghasilan lebih besar daripada istri. Posisi informan dalam kondisi demikian istri tetap terdominasi lebih oleh unsur partially (struktur-kultur). Pada hubungan relasi ini kapital tidak berperan, berpengaruh dalam dominasi.

Tabel 2 menunjukkan, kekerasan yang dialami oleh istri. 
Tabel 2.

Viktimisasi dalam Kontek Kekerasan dalam Rumah Tangga

\begin{tabular}{|c|c|c|}
\hline No. & $\begin{array}{c}\text { Aspek Viktimisasi dalam } \\
\text { Konteks KDRT }\end{array}$ & Informan II \\
\hline 1 & Kekerasan fisik & $\begin{array}{l}\text { - Istri dianggap sebagai pembantu, harus } \\
\text { mengerjakan semua pekerjaan rumah } \\
\text { tangga, khususnya urusan suaminya, } \\
\text { padahal mempunyai pembantu rumah } \\
\text { tangga dan supir pribadi. }\end{array}$ \\
\hline 2 & Kekerasan seksual & $\begin{array}{l}\text { Dijodohkan orang tuanya, pada laki-laki } \\
\text { yang usianya jauh berbeda, padahal saat } \\
\text { itu mempunyai pacar. }\end{array}$ \\
\hline 3 & Kekerasan psikis & $\begin{array}{l}\text { - Setelah menikah hidupnya dikekang } \\
\text { (tidak boleh bawa mobil) } \\
\text { - Suami sangat pencemburu. } \\
\text { - } \quad \text { Tidak boleh dandan, bergaul. } \\
\text { - } \quad \text { Dijaga seperti menjaga barang pecah } \\
\text { belah. } \\
\text { - Sosialisasi perempuan yang ideal. }\end{array}$ \\
\hline 4 & Kekerasan ekonomi & $\begin{array}{l}\text { Perempuan punya pekerjaan dan } \\
\text { penghasilan tetapi dibebani oleh } \\
\text { pekerjaan domestik padahal pembantu } \\
\text { dan supir ada. }\end{array}$ \\
\hline
\end{tabular}

Sumber: Hasil Penelitian, 2015

\section{Ketiga, Partially Dominated - Fully Capital \\ (Dominasi suami sebagian - Kapital suami penuh)}

Istri menjadi korban, walaupun tidak didominasi oleh suami yang mempunyai kepemilikan modal. Istri dalam hal ini tidak terdominasi (memiliki posisi yang setara). Secara struktural, baik suami maupun istri, mampu menempatkan posisi masing-msing sebagai porsi yang setara. Secara kultural mereka bukan berasal dari keluarga yang patriarki. Secara kapital, istri tergantung pada suami karena ia tidak bekerja.

Tabel 3. menunjukkan kekerasan yang dialami perempuan. 
Tabel 3.

Viktimisasi dalam Kontek Kekerasan dalam Rumah Tangga

\begin{tabular}{llll}
\hline No. & $\begin{array}{c}\text { Aspek Viktimisasi dalam } \\
\text { Konteks KDRT }\end{array}$ & & \multicolumn{1}{c}{ Informan I } \\
\hline 1 & Kekerasan fisik & $\bullet$ & Sering dipukuli suami (mata memar) \\
& & $\bullet$ & Diperlakukan semaunya. \\
\hline 2 & Kekerasan seksual & $\bullet$ & Hamil lebih dahulu. \\
\hline 3 & Kekerasan psikis & $\bullet$ & Merasa dipermainkan karena suaminya \\
& & & tidak mau menikah secara sipil (bukan sirri). \\
& & - & Merasa ragu, suaminya mencintai atau \\
& & & tidak. \\
& &
\end{tabular}

$4 \quad$ Kekerasan ekonomi

Sumber: Hasil Penelitian, 2015

\section{Keempat, Irrational Dominated - Capital (Dominasi - Kapital Irasional)}

Istri tidak selalu menjadi korban, pada kondisi tertentu ia menjadi korban, yakni pada saat mengalami dominasi. Walaupun dalam posisional struktural, kultural dan kapital tidak terdominasi tetapi dalam kenyataannya informan tetap merasa 'kalah', bahkan dalam batas tertentu merasa wajar jika berada dalam dominasi. Tabel 4. menunjukkan kekerasan yang dialami istri.

Tabel 4.

Viktimisasi Dalam Kontek Kekerasan dalam Rumah Tangga

\begin{tabular}{llll}
\hline No. & $\begin{array}{c}\text { Aspek Viktimisasi dalam } \\
\text { Konteks KDRT }\end{array}$ & & \multicolumn{1}{c}{ Informan IV } \\
\hline 1 & Kekerasan fisik & - & $\begin{array}{l}\text { Dipaksa hubungan seksual walaupun sedang } \\
\text { capek, sakit maupun menstruasi. }\end{array}$ \\
\hline 2 & Kekerasan seksual & $\bullet$ & $\begin{array}{l}\text { Suaminya cemburuan, Informan IV merasa } \\
\text { dikekang. }\end{array}$ \\
\hline 3 & Kekerasan psikis & $\bullet$ & Selalu diawasi kemana ia pergi, di-SMS, telepon. \\
& & Tidak bisa bebas, belanja ditemani. \\
& & $\bullet$ & Perempuan punya pekerjaan dan penghasilan. \\
\hline 4 & Kekerasan ekonomi & &
\end{tabular}

Sumber: Hasil Penelitian, 2015 


\section{Kelima, Non Dominated - Non Capital}

\section{(Tidak di dominasi dan Kepemilikan Modal Tidak Ada)}

Catatan: hasil penelitian lapangan, terhadap 4 informan, tidak seorang pun yang masuk dalam tipologi ini. Karena tidak ada informan yang tidak mengalami dominasi dalam pengalamannya berumah tangga.

\section{Penghukuman terhadap Perempuan Pelaku "Pembunuhan" dalam Kajian Kriminologi}

\section{Perempuan Pelaku Pembunuhan adalah Korban}

Dalam kajian kriminologi, perempuan pelaku pembunuhan bisa dikatakan kejahatan yang 'khas', dimana pelaku merupakan korban. Kejahatan diartikan dalam kriminologi, adalah sebagai pola tingkah laku yang merugikan masyarakat, baik secara fisik maupun materi, baik yang dirumuskan dalam hukum, maupun tidak. Sementara batasan kejahatannya, adalah menurut persepsi masyarakat dan bukan batasan hukum (pidana). ${ }^{19}$

Kajian dalam tulisan ini, adalah kajian feminis, khususnya feminis radikal. Posisi perempuan pelaku pembunuhan dalam konteks KDRT, secara normatif adalah orang yang bersalah melanggar hukum pidana. Standpoint penulis, memposisikannya sebagai korban, seperti kerangka pemikiran Gambar 2.

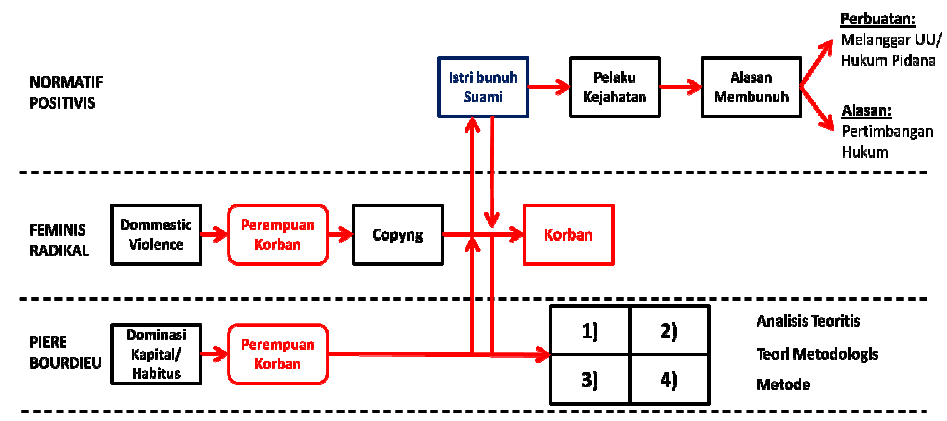

Gambar 2.

Standpoint penulis, memposisikannya sebagai korban

${ }^{19}$ Muhammad Mustofa, Metodologi Penelitian Kriminologi, 3 ed. (Jakarta: Fajar Interpratama Mandiri, 2013), 9-10. 
Model pemikiran yang digunakan oleh penulis dalam analytical theori ini adalah "kekerasan simbolik" dari teori Bourdieu yang digabungkan dengan Teori Feminis Radikal. Bourdieu membahas dalam kekerasan simbolik, adanya dominasi. Pembahasan Bourdieu yang sifatnya umum, dipadukan dengan Teori Feminis Radikal, yang penulis anggap relevan karena membahas masalah perempuan dan juga mendasari, adanya dominasi dalam keluarga (masyarakat patriarkhi). Berikut ini ilustrasi penjelasan tentang hubungan aktor/agen (= perempuan pelaku pembunuhan) dengan struktur/sistem dalam penulisan ini.

Dalam teori Bourdieu, perempuan pelaku pembunuhan diposisikan sebagai agen (aktor) yang mempunyai habitus. Ia dibekali dengan serangkaian skema terinternalisasi yang digunakan untuk mempersepsi, memahami, mengapresiasi, dan mengevaluasi dunia sosialnya. Melalui skema inilah ia menghasilkan praktiknya, memersepsikan dan mengevaluasinya. Secara dialektis, habitus adalah "produk dari internalisasi struktur" dunia sosial. Habitus bisa juga dianggap sebagai "akal sehat".

Posisi perempuan (istri) dalam keluarga, ditentukan oleh besarnya modal yang dimiliki dan sesuai dengan bobot komposisi keseluruhan modalnya. Perempuan diasumsikan hidup membentuk keluarga, dalam masyarakat patriarki. Menurut Bourdieu, dalam masyarakat ada yang dikuasai dan menguasai. begitu juga dalam keluarga, ada yang mendominasi dan ada yang didominasi. Dominasi laki-laki, karena kelas yang dimilikinya, menciptakan kekerasan simbolik pada perempuan, istrinya. Perempuan yang didominasi mengalami kekerasan simbolik, karena kepemilikan modalnya yang terbatas. Kepemilikan modal ini menentukan kelas secara vertikal, menurut Bourdieu.

Perempuan mengalami 'kekerasan simbolik', terjadi dominasi laki-laki melalui wacana (dalam relasi keluarga, masyarakat). Dominasi laki-laki yang terjadi, kadang dianggap sebagai suatu yang alamiah dan bisa diterima, hal ini merupakan kekerasan. Dibalik konsepsi ini telah terjadi suatu proses yang bertanggung jawab atas perubahan dari sejarah menjadi seakan-akan sesuatu yang alamiah dari suatu budaya menjadi seakan-akan sesuatu yang sudah diterima semestinya. Dalam konteks ini, menurut feminis radikal adalah budaya patriarki. Pada dasarnya kekerasan simbolik berlangsung karena ketidaktahuan dan pengakuan dari yang tertindas. Dalam konteks ini, yang jadi korban (tertindas) adalah perempuan pelaku pembunuhan. 
Jadi sebetulnya logika dominasi ini bisa berjalan karena prinsip simbolik yang diketahui dan diterima baik oleh yang menguasai maupun yang dikuasai. Prinsip simbolik ini merupakan bahasa, gaya hidup, cara berfikir, cara bertindak, dan kepemilikan khas pada kelompok tertentu atas dasar ciri kebutuhan. Peran faktor simbol-nilai sangat tampak pada perempuan pelaku pembunuhan.

Kate Millet mengatakan patriarki dibawa oleh kontrol gagasan dan kebudayaan oleh laki-laki, sebenarnya tidak hanya terbatas pada arena kekerabatan saja, tetapi juga pada semua arena kehidupan manusia, seperti ekonomi, politik, keagamaan dan seksualitas.

Relasi gender dalam keluarga, pada masyarakat patriarki menunjukkan ketidaksetaraan, dimana terjadi dominasi. Penggunaan kekuasaan oleh laki-laki terhadap perempuan ditemukan tidak hanya dalam konteks publik-strutural dan ideologi dalam pekerjaan, pendidikan, media dan seterusnya. Yang sama pentingnya adalah patriarki pada tingkat personal, dalam dunia pribadi, hubungan intim laki-laki dan perempuan.

Sebagai contoh, adanya 'perempuan ideal'20 dan bagaimana agama mempengaruhi kehidupan perempuan. Bagaimana pemahaman agama yang keliru, dimana perempuan menerapkan pengetahuannya 'mengabdi pada suami dengan 'membabi buta', menerima kekerasan sebagai suatu bukti, ia berbakti pada suaminya'. Begitu juga dengan ideologi gender ${ }^{21}$ yang berpengaruh dalam kehidupan perempuan, karena tersosialisasi sejak kecil, maka seperti yang dikatakan Bourdieu, proses ini merupakan suatu budaya yang menjadi seakanakan sebagai sesuatu yang sudah semestinya. Contohnya: perempuan dibiasa-

${ }^{20} \mathrm{Gambaran}$ perempuan dalam kitab ini (tafsir) tidak jauh dari gambaran perempuan ideal yang ditulis kebanyakan pembuat hukum zaman abad pertengahan. Menurut hukum yang berlaku, perempuan ideal adalah mereka yang jarang bicara, dan tertawa tanpa sebab. Perempuan yang tidak pernah meninggalkan rumah, bahkan untuk menemui tetangganya yang dikenalnya. Perempuan yang tidak mempunyai teman-teman perempuan, tidak memberikan kepercayaan pada siapapun. Dan perempuan yang menjadikan suaminya sebagai satu-satunya tempat bergantung. Baca: Ratna Batara Munti, "Perempuan dalam Perspektif Tradisi Islam dari Timur Tengah Hingga Indonesia," Jurnal Perempuan 3, no. Mei-Juni (1999), 15-6.

${ }^{21}$ Ideologi gender adalah segala aturan, nilai, stereotip yang mengatur hubungan antara perempuan dan laki-laki terlebih dulu melalui pembentukan identitas feminin dan maskulin. Ratna Saptari dan Brigitte M. Holzner, Perempuan, Kerja, dan Perubahan Sosial: Sebuah Pengantar Studi Perempuan (Jakarta: Pustaka Utama Grafiti, 1997), 202. 
kan untuk mengerjakan pekerjaan domestik, sebaliknya laki-laki untuk pekerjaan publik, atau, perempuan dianggap wajar dalam menyelesaikan masalahnya menggunakan emosi yang berlebihan, seperti menangis, sementara laki-laki, tabu untuk menangis. Karena sudah diajarkan laki-laki adalah pemberani, pelindung perempuan, pembela keluarga, dan sebagainya.

\section{Penghukuman yang Belum Berpihak kepada Korban}

Kebijakan hukum atas kasus Istri yang dituduh 'membunuh' suaminya, diputuskan pengadilan tanpa merujuk pada kasus kekerasan dalam rumah tangga yang dialami 'pelaku' (istri yang dituduh 'membunuh' suami), dimana pengalaman mereka menunjukkan mereka adalah korban kekerasan dalam rumah tangga. Dalam hal ini, hasil lapangan menunjukkan beragamnya hukuman yang dijatuhkan pada informan, padahal semua informan berada dalam keadaan sedang berumah tangga. Penghukuman tersebut, tidak semua menggunakan UU Penghapusan Kekerasan dalam Rumah Tangga No. 23 Tahun 2004.

Merujuk hal tersebut, dalam kenyataannya Undang-Undang tidak berperspektif perempuan, fungsinya belum dapat mengakomodir semua perempuan. Berdasarkan penelitian, ke-4 informan penulis berada dalam lingkup rumah tangga, tetapi disayangkan UU yang dipergunakan tidak sama, bukan UU Penghapusan KDRT. Untuk informan II dan IV, walaupun masih dalam lingkup rumah tangga yang digunakan adalah KUHP, padahal mereka berdua juga tidak terbukti membunuh. Kenapa UU PKDRT tidak bisa diterapkan untuk semua kasus dalam rumah tangga, padahal dalam UU tersebut, menyebutkan semua yang ada dalam rumah tangga. Keputusan ini, semua tergantung pada kemampuan hakim dalam memahami kasus-kasusnya, dan mengertinya terhadap UU yang berbeda dengan yang biasa dipergunakan KUHP.

\section{E. Kesimpulan}

Melalui kajian kriminologi ini, menyadarkan orang bahwa perempuan atau istri yang secara normatif membunuh suaminya, tidak bisa disalahkan. Berdasarkan pengalaman mereka, mereka mengalami viktimisasi, terjadi dominasi dalam keluarga. Jadi tidak tepat penghukumannya dengan menggunakan hukuman yang sama untuk setiap kasus pembunuhan (KUHP). Harus 
ada alternatif penyelesaian masalah, bisa dalam bentuk penghukuman yang berbeda. Yang diperlukan adalah bentuk penghukuman yang berbeda yang disesuaikan dengan konteksnya, dimana mereka adalah korban KDRT, seperti rehabilitasi atau menjadikannya sebagai pekerja sosial.

Tetapi sayangnya UU PKDRT ini belum mengakomodir kepentingan perempuan, atau belum berperspektif korban. Disebabkan seperti kita ketahui bersama bahwa Sistem Peradilan Pidana bergantung pada tekanan normatif untuk mengendalikan kejahatan. Mekanisme normatif' dari pengawasan kejahatan bekerja melalui jalan resmi untuk membawa pelaku suatu perilaku yang dilarang sebagai sesorang yang tidak konsisten dengan norma-norma hukum, sehingga apapun alasannya pelaku tersebut harus dihukum. Alasan melakukan perilaku yang dilarang hanya digunakan sebagai alasan menjatuhkan hukuman, ringan hingga berat.22

Sebagaimana dinyatakan di atas, undang-undang ini mengakui bahwa penggunaan kekuatan untuk membela diri dapat dibenarkan. Temuan pembenaran merupakan temuan bahwa tindakan itu benar karena keadaan dari tindakan itu. Sebaliknya, tindakan dimaafkan adalah salah satu yang, meskipun salah, harus ditoleransi karena karakteristik aktor. ${ }^{23}$

Karena hukum memandang bela diri sebagai tindakan dibenarkan, hukum juga menuntut bahwa tindakan ini masuk akal, dengan demikian, keadaan tindakan membela diri harus membenarkan tindakan tersebut. Suatu tindakan yang dilakukan untuk membela diri itu dibenarkan mengingat aktor individu sedang melindungi dirinya walaupun akibatnya menimbulkan kematian bagi orang lain. ${ }^{24}$ Bagaimanapun hukum melihat alasan hanya setelah pembenaran gagal. 25

${ }_{2}^{22}$ Natalie J. Sokoloff dan Ida Dupont, "Domestic Violence at the Intersections of Race, Class, and Gender," Violence Against Women 11, no. 1 (2005): 38-64, https://doi.org/10.1177/ 1077801204271476.

${ }^{23}$ Hammed Shahidian, "Gender and Sexuality Among Immigrant Iranians in Canada," Sexualities 2, no. 2 (1999): 189-222, https://doi.org/10.1177/136346079900200203.

${ }^{24}$ Angela Maria Toffanin, "Research on Violence against Women: A Sociological Perspective," Interdisciplinary Journal of Family Studies 17, no. 1 (2012): 15-30, http://ijfs.padovauniversitypress.it/ system/files/papers/17_1_03.pdf.

${ }_{25}^{25}$ Toffanin. 
Lalu bagaimana istri yang membunuh suami karena membela diri atas proses viktimisasi yang diterimanya dari suaminya? Dalam kasus 4 informan yang dituduh sebagai 'pembunuh' suaminya, pengalaman mereka menunjukkan kalau mereka adalah korban dari kekerasan dalam rumah tangga. Bentukbentuk kekerasan dan variasinya terjadi pada saat mereka menjalani kehidupan rumah tangga. Feminis radikal menunjukkan, mereka semua adalah korban, walaupun secara yuridis, normatif mereka sudah diputuskan oleh pengadilan sebagai pelaku kejahatan pembunuhan. Berdasarkan pengalaman viktimisasi yang terjadi, dan kemudian, dominasi yang mereka alami, Teori Bourdieu menunjukkan adanya variasi dalam dominasi tersebut (Lihat Tipologi Dominasi-Kapital).

Beragamnya, pengalaman mereka sebagai korban KDRT, diakhiri semuanya dengan kematian suaminya. Pada informan yang mengalami dominasi penuh, rasa syukur atas kematian tersebut, karena berakhir juga proses kekerasan yang dialaminya. Walaupun, pada sisi lain tetap merasa kehilangan, dan menganggap semua kekerasan adalah wajar (kekerasan simbolik). Begitu juga dengan informan II, yang mempunyai suami posesif, walaupun memiliki posisi dalam kapital, bukan berarti tidak mengalami dominasi. Dan informan I, walaupun mempunyai kedudukan setara dengan suaminya, tetap juga mengalami dominasi. Dan yang khas, adalah informan IV, pada kondisi tertentu mengalami dominasi, kondisi lain bisa disiasati dengan adanya pasangan lain.[s]

\section{Daftar Pustaka}

Gilfus, Mary E., Nicole Trabold, Patricia O’Brien, dan Ann Fleck-Henderson. "Gender and Intimate Partner Violence: Evaluating the Evidence." Journal of Social Work Education 46, no. 2 (2010): 245-63. https://doi.org/ 10.5175/JSWE.2010.200900019.

Gosita, Arif. "Pemahaman Perempuan dan Kekerasan." Dalam Masalah Korban Kejahatan: Kumpulan Karangan. Jakarta: Penerbit Universitas Trisakti, 2004. 
Kim, Bitna. "General Power-Control Theory of Women: Using a Multigroup SEM Approach to Testing Mean Differences." Sam Houston State University, Huntsville, 2008.

Kim, Bitna, Jurg Gerber, Craig Henderson, dan Yeonghee Kim. "Applicability of General Power-Control Theory to Prosocial and Antisocial Risk-Taking Behaviors Among Women in South Korea." The Prison Journal 92, no. 1 (2012): 125-50. https://doi.org/10.1177/0032885511429275.

Kim, Bitna, dan Victoria B. Titterington. "Abused South Korean Women: A Comparison of Those Who Do and Those Who Do Not Resort to Lethal Violence." International Journal of Offender Therapy and Comparative Criminology 53, no. 1 (2009): 93-112. https://doi.org/10.1177/ $0306624 X 07312772$.

Kim, Bitna, Victoria B Titterington, Yeonghee Kim, dan William Wells. "Domestic Violence and South Korean Women: the Cultural Context and Alternative Experiences." Violence and Victims 25, no. 6 (2010): 814-30. http://www.ncbi.nlm.nih.gov/pubmed/21287969.

Komisi Nasional Anti Kekerasan terhadap Perempuan. "Kekerasan terhadap Perempuan Meluas: Negara Urgen Hadir Hentikan Kekerasan terhadap Perempuan di Ranah Domestik, Komunitas dan Negara: Catatan Kekerasan terhadap Perempuan tahun 2015," 2016. https://www. komnasperempuan.go.id/reads-catatan-tahunan-tentang-kekerasanterhadap-perempuan-2016.

Komnas Perempuan. "Konvensi tentang Penghapusan Segala Bentuk Diskriminasi terhadap Perempuan." Jakarta: Komnas Perempuan, 2002.

Krug, Etienne G., James A. Mercy, Linda L. Dahlberg, dan Anthony B. Zwi. “The World Report on Violence and Health." The Lancet 360, no. 9339 (2002): 1083-88. https://doi.org/10.1016/S0140-6736(02)11133-0.

Lorber, Judith. "The Social Contruction of Gender." In The Social Construction of Difference and Inequality: Race, Class, Gender and Sexuality, ed. Tracy E. Ore. California: Mayfield Publhising Company, 2000.

Miler, Susan L. "Arres Policies for Domestic Violence and Their Implication for Baterred." In It is a Crime, Women and Justice, diedit oleh Roslyn Muraskin. Upper Sadle River, New Jersey: Long Island University, 2000.

Munti, Ratna Batara. "Perempuan dalam Perspektif Tradisi Islam dari Timur Tengah Hingga Indonesia." Jurnal Perempuan 3, no. Mei-Juni (1999). 
Mustofa, Muhammad. Metodologi Penelitian Kriminologi. 3 ed. Jakarta: Fajar Interpratama Mandiri, 2013.

Saptari, Ratna, dan Brigitte M. Holzner. Perempuan, Kerja, dan Perubahan Sosial: Sebuah Pengantar Studi Perempuan. Jakarta: Pustaka Utama Grafiti, 1997.

Shahidian, Hammed. "Gender and Sexuality Among Immigrant Iranians in Canada." Sexualities 2, no. 2 (1999): 189-222. https://doi.org/10.1177/ 136346079900200203.

Sokoloff, Natalie J., dan Ida Dupont. "Domestic Violence at the Intersections of Race, Class, and Gender." Violence Against Women 11, no. 1 (2005): 38-64. https://doi.org/10.1177/1077801204271476.

Song-Kim, Y. I. "Battered Korean Women in The Urban United States." Dalam Social Work Practice With Asian Americans, ed. S. M. Furuto, D. K. Chung, K. Murase, dan F. Ross-Sheriff, 213-26. Newbury Park, CA: Sage Publication Inc., 1992.

Susanti, Vinita. "Pembunuhan oleh Istri dalam Konteks Kekerasan dalam Rumah Tangga (KDRT): Studi terhadap Empat Terpidana Perempuan di Lembaga Pemasyarakatan Wanita Bandung." Disertasi. Departemen Sosiologi, FISIP UI, Depok, 2015.

_- - "The Typology of Women Victims Domination of Domestic Violence: Study of Gender Equality in Women's Prison in Bandung." Dalam Proceeding Re-examining Governance: Strengthening Citizenship in the Changing World - ICoCSPA 2016, 77-81. Surabaya: FISIP Universitas Airlangga, 2016.

Toffanin, Angela Maria. "Research on Violence against Women: A Sociological Perspective." Interdisciplinary Journal of Family Studies 17, no. 1 (2012): 1530. http://ijfs.padovauniversitypress.it/system/files/papers/17_1_03.pdf.

Wolfgang, Martin F. "Victim Precipitated Criminal Homicide." Journal of Criminal Law and Criminology 48, no. 1 (1957): 1-11. https://scholarlycommons. law.northwestern.edu/jclc. 
This page intentionally left blank 